\title{
Biological activity evaluations of chemical constituents derived from Mongolian medicinal forage plants and their applications in combating infectious diseases and addressing health problems in humans and livestock
}

\author{
Toshihiro Murata ${ }^{1}$ (D) Javzan Batkhuu ${ }^{2}$
}

Received: 27 January 2021 / Accepted: 6 May 2021 / Published online: 21 May 2021

(c) The Author(s) 2021

\begin{abstract}
Mongolian nomadic people possess traditional knowledge of wild plants that grow in their areas of habitation. Many of these are forage plants in nature and are consumed by livestock. However, these plants are known to have medicinal and/or toxic properties. To establish a scientific understanding of the plants, and in turn, offer sound knowledge on their applications and effective use, it is essential to collect data pertaining to the chemical constituents of each plant. Therefore, the first objective of this study was to identify and determine the structural constituents of the forage plants that were available to our research group. Furthermore, in an attempt to demonstrate the biological activities of the isolated chemical compounds, we focused on solving some of the social issues affecting Mongolian communities, including protozoan diseases affecting livestock, vectors of infectious diseases, and the general health of humans and their livestock. The results of the chemical constituents derived from Mongolian medicinal plants and their biological activities that were studied in the recent decade are also described herein.
\end{abstract}

\section{Graphic abstract}

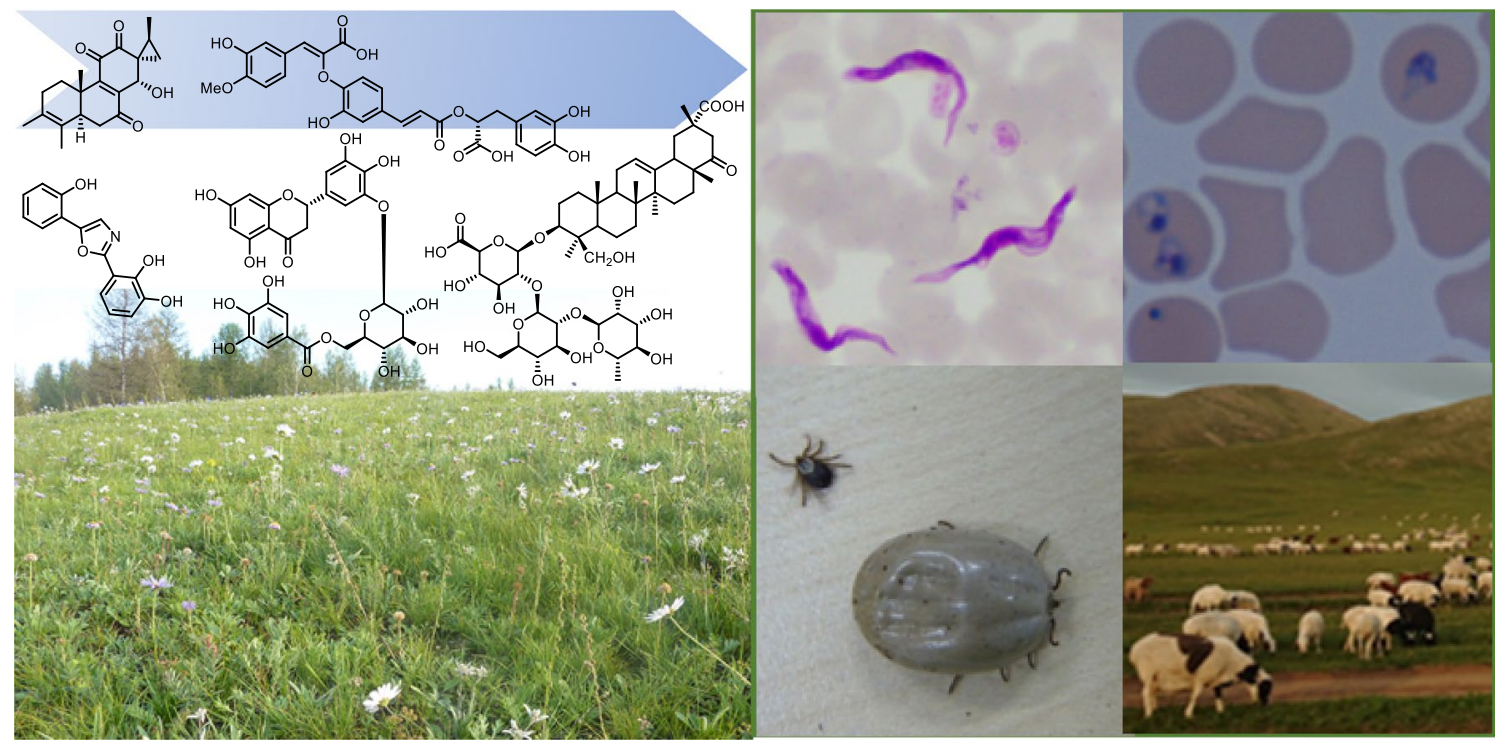

Keywords Mongolian $\cdot$ Medicinal $\cdot$ Forage $\cdot$ Native $\cdot$ Chemical $\cdot$ Constituents

Extended author information available on the last page of the article 


\section{Introduction}

A total of 3191 species of vascular plants belonging to 684 genera and 108 families account for the total plant population of Mongolia [1, 2]. Many of these plants are known to be useful to humans and livestock, with Mongolian people including nomads, appreciating the relationship between medicinal forage plants, and the well-being of humans and livestock. This knowledge has been passed on as a tradition from one generation to another. The Mongolian population uses medicinal prescriptions referred to as "jor" as well as medicinal herbs growing in the wild to prevent and cure many diseases. Mongolian traditional medicine is classified into the following categories, namely massage, acupuncture, herbal medicine, dietary cures, aromatherapy, phlebotomy, and sutra recitation. Herbal medicines are one of the principal remedies, which are thought to be derived from Tibetan traditional medicine [3, 4]. Although there are a few notable differences between the theories of herbal medicine and herbal sources of Mongolia and those of other countries, there are also some aspects in common. Herbal plant sources that are commonly used worldwide are abundant throughout Mongolia. These include the Ephedra herb and the Glycyrrhiza root [3], as well as the Astragalus root, Scutellaria root, Bupleurum root, Saposhnikovia root and rhizome [5], and peony root [6]. The aforementioned plants are important constituents of herbal drug formulations in various countries, including the Japanese Kampo formula. Descriptions about the sources of plants for Mongolian crude drugs are listed in the Mongolian national pharmacopeia published in 2011 (1st edition, Ministry of Health, Mongolia), and the animal drug pharmacopeia which is published by the Ministry of Food, Agriculture and Light Industry.

In addition to the plants used as raw materials for crude drugs, many continental plants that are freeze-proof and drought-tolerant are widely available in Mongolia [7], and the Gobi Desert [8]. These plants are distributed in severe environments with harsh conditions. The territory of this country is marked by diverse land with six natural vegetation zones from the north to the south: high mountain zone, taiga forest zone, mountain forest-steppe zone, steppe zone, desert steppe zone, and Gobi Desert zone [9]. In addition, a large variety of the continental climates in Mongolia result in rich biodiversity in each of the zones [10]. Many of the plants in this region have been known to possess chemical constituents that benefit humans, domestic livestock, and the surrounding ecosystem.

Some international and/or domestic groups have identified and characterized plants with medicinal benefits using scientific methods. The reports compiled from these investigations highlighted the features of the plants, including their distributions, usage, origins, medicinal components, and traditional history $[7,8,11-14]$. In addition, many researchers have studied the chemical constituents of wild plants in depth to determine their medicinal uses [15]. Nonetheless, due to the complexity of biological and ecological systems, frontier research continues to be relevant. Consequently, there is a need to investigate the biological activities of phytochemicals and their interactions with humans and animals to understand how these chemicals can be used more effectively.

Some of the significant plant resources of Mongolia are limited and have led to the publication of the endangered species list $[2,8,16]$. Although many researchers, including our own research group, have demonstrated fundamental aspects of various plants, further in-depth discussions are required on how to use these plants sustainably. Knowledge of the chemical constituents of each plant is fundamental data that is crucial in understanding the scientific features of the specific plant. The current research focused on the chemical constituents and biological activities of the Mongolian native plants and fungi, by investigating their traditional usage and collating information on their pharmacological effects and toxicity on animals.

\section{Attractive features of Mongolia, and the current problems that need attention}

The flower blooming plateau that extends beyond the horizon is recognized as one of the unique characteristic points of Mongolia (Fig. 1a). Over $20 \%$ of the population in Mongolia have adopted a nomadic lifestyle, with stock farming being one of the most important industries of the community. In 2016, the gross domestic product (GDP) ratio of the agricultural and livestock sectors accounted for $12.2 \%$ (second largest following the mining sector), which indicates the importance of the livestock sector in supporting the economy [17, 18]. Horses, cows, sheep, goats, and camels are among the five main livestock categories of the Mongolian community. In recent years, there have been over 60 million different heads of livestock in the Mongolian land (Fig. 1h) [17], and the latest report estimates around 70 million heads of animals [19]. The livestock is 20-25 times the population of the country. Although it is assumed that livestock graze freely, each animal has different palatability to forage plants of the Mongolian rangeland [20,21].

Infectious diseases pose a threat while striving to attain a stable economy that depends on healthy human and livestock populations. In addition, livestock diseases and zoonosis are factors that contribute to the collapse of economies in nomadic communities. Protozoal diseases are caused by infectious protozoa, including Trypanosoma, Babesia, and Theileria. In Mongolia, Trypanosoma equiperdum infections in horses [22] and Babesia and 
Fig. 1 a Flower blooming plateau in Mongolia b Trypanosoma equiperdum (Photo by Dr. K. Suganuma), c Babesia caballi (Photo by Dr. B. Tuvshintulga), d Theileria equi (Photo by Dr. B. Tuvshintulga), e Ticks waiting for animals on a dried stem of a plant in early spring, $\mathbf{f}$ A tick sucking goat blood, $\mathbf{g}$ Ticks before and after sucking blood, h Livestock on the Mongolian steppe
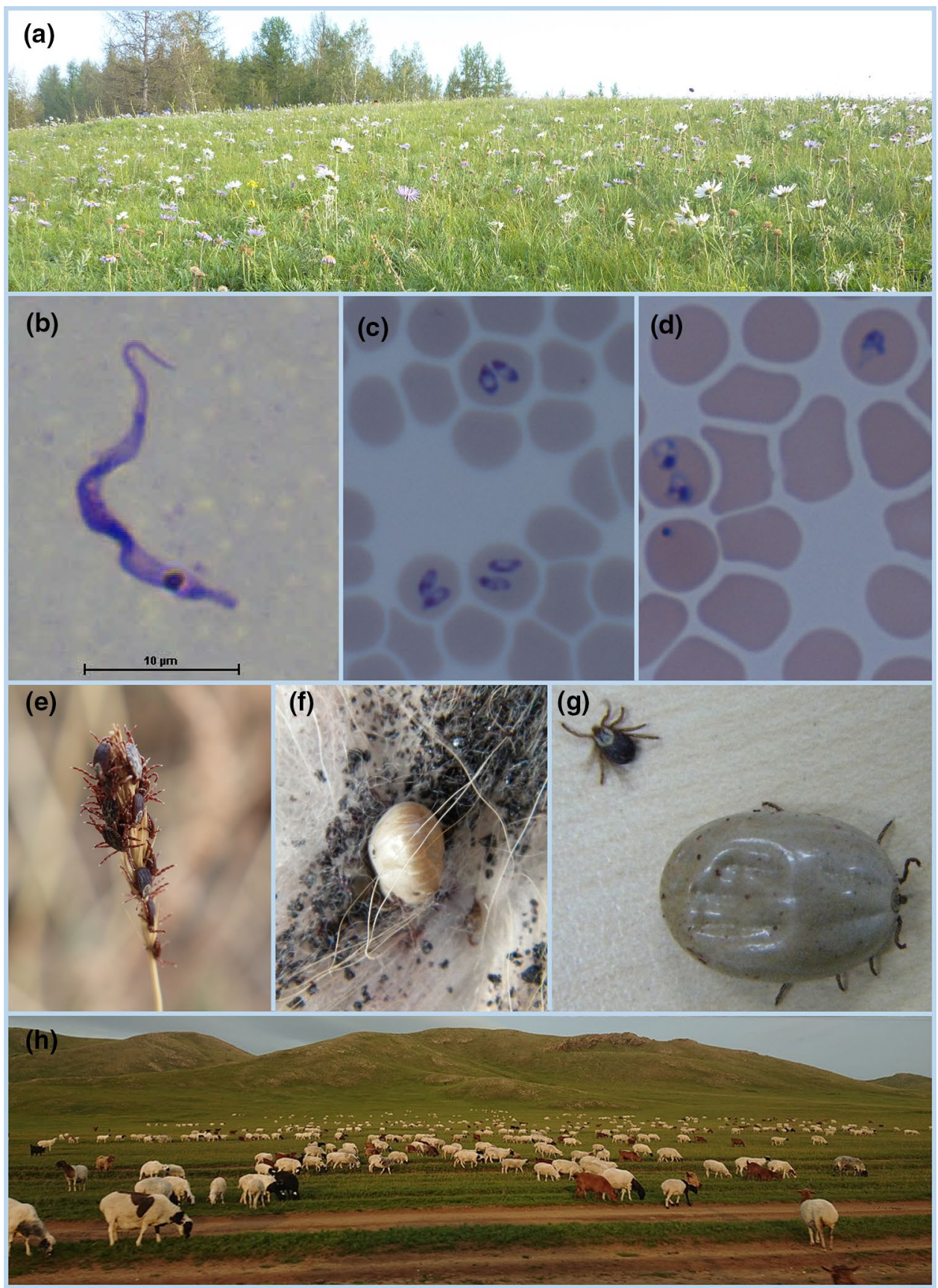

Theileria infections in cattle [23] and horses [24] have been reported (Fig. 1b-d). Infected livestock become weak and lose their value. Moreover, severe natural disasters like "Dzud" cause the death of many of the weakened animals [25]. The Babesia and Theileria protozoans are mediated by ticks, including Dermacentor nuttalli [26]. Many ticks tend to parasitize thin animals after the winter season (Fig. 1e-g), resulting in health issues in these animals, such as loss of physical strength and reduced quality and quantity of its milk and meat. The bite marks and visual changes in the skin around these marks due to infestation by ticks, ultimately result in loss of potential value of the animal's fur. Unfortunately, some of the animals are infected by pathogens that are tick-borne. Apart from ticks, unsanitary insects and small animals are also a cause for concern. Bacterial infectious diseases caused by Yersinia pestis and Bacillus anthracis as well as viral diseases have been reported. Although these diseases are rare, they are sometimes zoonotic and can cause fatality in the infected patients [27]. Infectious diseases are not confined to Mongolia alone, but are rather one of the widespread challenges that need worldwide attention 
[28]. New drugs that can eliminate pathogens are continuously being sought out, with strategies aiming to target the vector being one of the measures to prevent disease transmission. Nomads have been using many wild plants to cure infectious diseases, provide symptomatic relief, and remove epizoic insects and ticks of livestock since ancient times. Thus, it is important to study Mongolian plants to discover components with potential medicinal benefits against infectious diseases.

Apart from the effects on animals alluded to above, severe climates also have a direct and indirect effect on human life. Populations have concentrated in the urban areas because of the modernization of life, and it is feared that a potential dilution of the Mongolian traditions will occur due to a decrease in the nomadic community [29, 30]. Cold winters, dry summers, and strong sunshine over $1300 \mathrm{~m}$ above sea level cause problems such as skin conditions in native inhabitants. Recently, people in the urban areas have begun to worry about skin problems and allergies caused by various factors, including pollen.

Contrary to the fact that the population of nomads is decreasing because of economic development, livestock farming has continued to increase in Mongolia [29]. Plant resources have depleted in these areas due to excessive livestock farming. Rangelands that previously had various plant species growing in them have now become areas with plentiful growth of only Artemisia plants [31]. Moreover, some of these areas became desertified, which in turn exacerbated the difficulty in maintaining the quality of meat and milk of livestock. Furthermore, some countries prohibit the sale of Mongolian meat because the concentrations of antibiotics in the meat appear to exceed reference values. To solve these problems, a scientific approach to study the chemical interactions between forage plants and livestock is essential.

\section{Our approach to solving the problems using plants and their chemical constituents}

Our research objective proposed to establish solutions to the above-mentioned problems using Mongolian plant resources and their chemical constituents. During the last decade, in a collaborative research project, a total of 373 chemical compounds (including over 110 new natural products) were identified from plants and fungi in Mongolia (Table S1, Supplementary Information). These compounds included alkaloids, flavonoids, phenylpropanoids, lipids, terpenoids, saponins, glycosides, and their derivatives. An in-depth evaluation of the isolated compounds to determine their pharmaceutical properties was conducted in an attempt to solve the abovementioned problems experienced by the Mongolian community [32-55].

\section{Trypanocidal activity}

In a collaborative research project conducted along with a veterinary group, various types of antiprotozoal compounds were isolated and identified from Mongolian medicinal plants. Oxytropis lanata is a perennial herb belonging to the family Fabaceae. Oxytropis lanata is used to treat fractures, wounds, and reduce inflammation. From this plant, eleven 2,5-diphenyloxazoles were isolated together with six known isoflavonoid derivatives. Oxazole-type alkaloids are rare natural products, but the oxazole structure is a fundamental moiety in certain pharmaceutical and drug candidate compounds. In the screening for trypanocidal activity against Trypanosoma congolense which causes the lethal disease "nagana" in animals, compound $\mathbf{1}$ (Fig. 2) showed the highest activity ( $\mathrm{IC}_{50} 1.0 \mu \mathrm{M}$ ) while compounds $\mathbf{2}-\mathbf{5}$ (Fig. 2) had potent activities $\left(\mathrm{IC}_{50} 6.0-14.8 \mu \mathrm{M}\right)$ [32]. In addition, lignans also presented as potent anti-Trypanosomal candidates. Characteristic acylated lignans were isolated from Brachanthemum gobicum (Asteraceae). They were isolated as pairs of enantiomers and their absolute configurations were determined from their optical rotations and electronic circular dichroism (ECD) spectra [33]. These Brachanthemum phenylpropanoid dimers (6-10, Fig. 2), sesamin from Artemisia sieversiana (Asteraceae), and some flavonoids from the above plants showed trypanocidal activity $\left(\mathrm{IC}_{50}\right.$ 2.4-10.0 $\mu \mathrm{M}$ ) [32, 34, 35]. Naranmandakh and coworkers also demonstrated lanostane triterpenoids, isolated from a fungus Fomitopsis officinalis in the family Polyporaceae [36], as active compounds. Trypanosoma congolense is transmitted by tsetse flies and causes severe animal diseases in African countries; however, this species is not widely distributed throughout Mongolia. Nevertheless, Suganuma and coworkers isolated and characterized the Mongolian Trypanosoma equiperdum strain that causes "dourine" [22]. Testing of the above active compounds to study their pharmaceutical effects on Mongolian T. equiperdum is expected to be undertaken as the next project because in vitro assay systems for this strain have been already established [37].

\section{Anti-piroplasm activity}

Piroplasmosis is caused by pathogenic protozoa of the genera Babesia and Theileria. Babesia bovis and B. bigemina infect cattle while equine piroplasmosis is caused by $B$. caballi and Theileria equi. These protozoal diseases cause hemolytic anemia, fever, hemoglobinuria, and splenomegaly in animals and negatively affect animal husbandry [23, 24, 38]. Saxifraga spinulosa belongs to the family Saxifragaceae and is known to be consumed by elks [20]. Badral and coworkers reported isolating galloyl glycosides, including flavonoids that have a glucosyl moiety connected to the $\mathrm{C}-3^{\prime}$ carbon of a pyrogallol B-ring, a rare structural feature, from this 


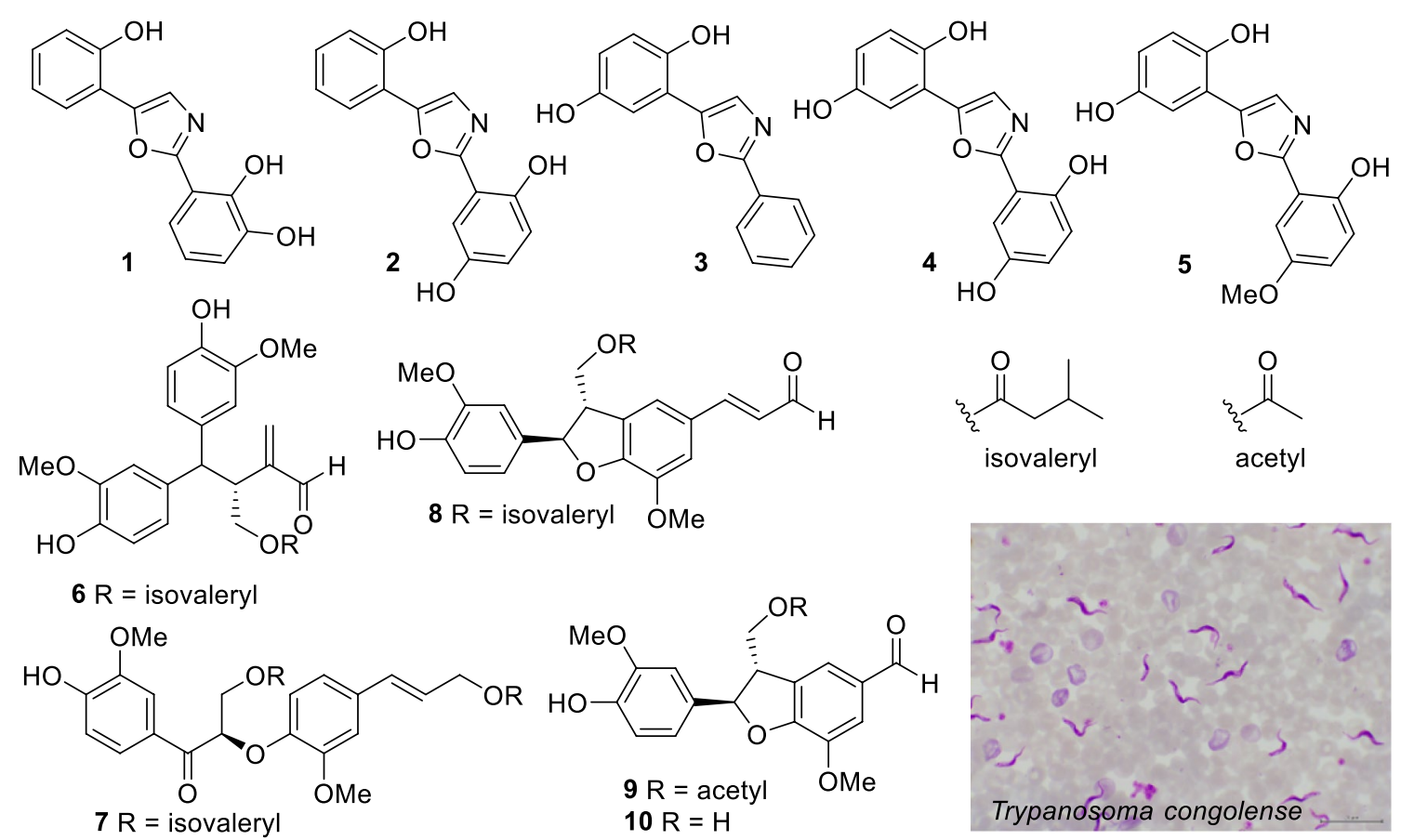

Fig. 2 Oxazoles isolated from Oxytropis lanata (1-5) and lignans from Brachanthemum gobicum (6-10) possess trypanocidal activity, and Trypanosoma congolense (Photo by Dr. K. Suganuma)<smiles>O=C(OC[C@@H]1O[C@H](COc2cc([C@H]3CC(=O)c4c(O)cc(O)cc4O3)cc(O)c2O)[C@H](O)[C@@H](O)[C@H]1O)c1cc(O)c(O)c(O)c1</smiles><smiles>Oc1cccc(O)c1</smiles><smiles>CC(=O)c1cc(O)c(O)c(O)c1</smiles>

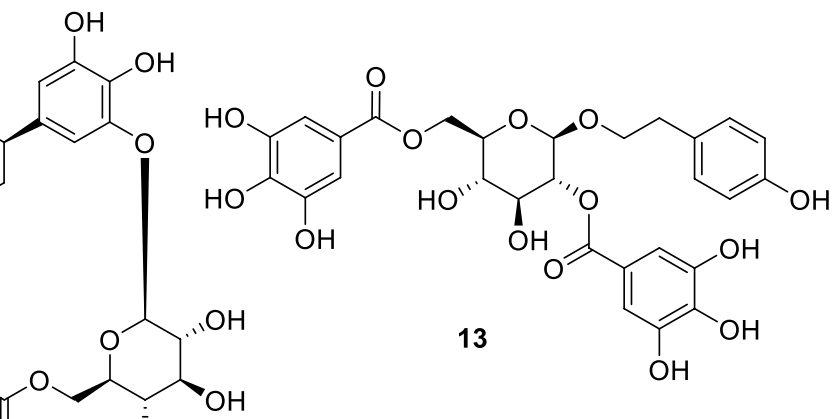

12<smiles>O=C(Oc1cc(O)c2c(c1)O[C@H](c1ccc(O)c(O)c1)C[C@@H]2OC(=O)c1cc(O)c(O)c(O)c1)c1cc(O)c(O)c(O)c1</smiles>

Fig. 3 Anti-piroplasma compounds isolated from Saxifraga spinulosa (11-13) and Bergenia crassifolia (14 and 15)

plant [38]. Although there were differences in sensitivity, the isolated compounds from this plant showed anti-piroplasm activity against some of the four strains described above. For example, new compounds $\mathbf{1 1}$ and $\mathbf{1 2}$ (Fig. 3) showed inhibitory activities against Babesia bovis and B. bigemina $\left(\mathrm{IC}_{50} 9.4 \sim 22.7 \mu \mathrm{g} / \mathrm{mL}\right.$ ), and compound 13 showed inhibitory activity against $B$. caballi $\left(\mathrm{IC}_{50} 15.6 \mu \mathrm{g} / \mathrm{mL}\right)$. The galloyl group is a key structure for anti-piroplasm activity, with 
experiments of flavonoids isolated from Bergenia crassifolia of the family Saxifragaceae (14 and 15, Fig. 3), supporting this conclusion [39]. Nonetheless, some flavan-3-ols without the galloyl group also showed moderate inhibitory activity against Babesia and Theileria [40].

\section{Virucidal and antibacterial activity}

Currently, humanity is facing a global catastrophe as the infectious disease Covid-19, which is caused by the severe acute respiratory syndrome coronavirus 2 (SARS-CoV-2), continues to spread. One of the ways to combat the spread of Covid-19 is to inactivate the SARS-CoV-2. Takeda and coworkers conducted virucidal screening against multiple viruses, using a library of extracts and compounds that was available to the group. In this study, fractions and some compounds, including gallocatechin gallate (GCG) $(\mathbf{1 6}$, Fig. 4) and epigallocatechin gallate (EGCG) (17, Fig. 4), from Saxifraga spinulosa showed potent activity against the influenza A virus, feline calicivirus, murine norovirus, and SARS-CoV-2 [41]. The effects of EGCG have been investigated by many groups because it is a typical tea catechin. However, the crude fractions of GCG and EGCG showed higher activities than GCG and EGCG. We propose the use of a more refined approach in the future to identify more effective components.

The search and isolation of new antibiotics continue to be a vital area of focus in research because of emerging drug-resistant bacterial strains. Caryopteris mongolica, a plant belonging to the family Lamiaceae, is moderately palatable to goats and horses [20]. Saruul and coworkers<smiles>O=C(O[C@H]1Cc2c(O)cc(O)cc2O[C@H]1c1cc(O)c(O)c(O)c1)c1cc(O)c(O)c(O)c1</smiles><smiles>[R]c1cc([C@H]2Oc3cc(O)cc(O)c3C[C@H]2O)cc(O)c1[C@@H]1Oc2cc(O)cc(O)c2C[C@H]1O</smiles>

$18 \mathrm{R}=\mathrm{OH}$

$20 \mathrm{R}=\mathrm{OH}$

$19 \mathrm{R}=\mathrm{H}$

$21 \mathrm{R}=\mathrm{H}$

Fig. 4 Catechin and its analogues (16-21)<smiles>CC[C@@]1(C)C2=C(C(=O)C(=O)C1O)[C@H](O)C1CCC(C)=C(C)C1CC2=O</smiles><smiles>CC(C)c1cc2c(c(O)c1O)[C@@]1(C)CCCC(C)(C)[C@H]1CC2=O</smiles><smiles>CC(C)c1cc2c(c(O)c1O)[C@@]1(C)CCCC(C)(C)[C@H]1[C@H](O)C2=O</smiles>

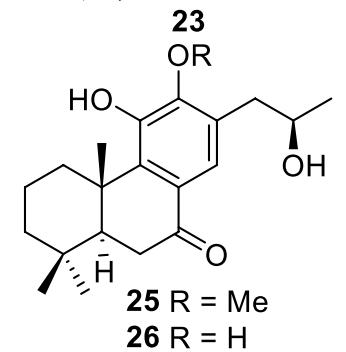

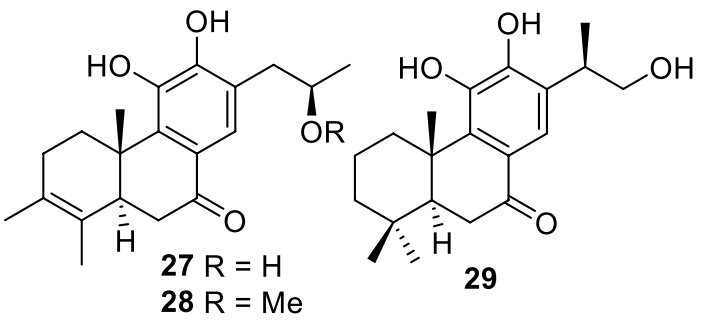<smiles>CC(O)Cc1c(O)c(O)c2c(c1O)C(=O)C[C@H]1[C@@H](C)CCC[C@]21C</smiles>

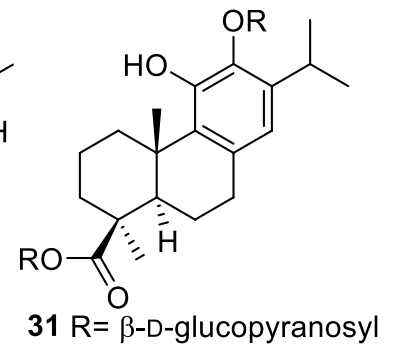

Fig. 5 Diterpenoids (22-31) isolated from Caryopteris mongolica possess antibacterial and cholinesterase inhibitory activities

isolated a diterpenoid (22, Fig. 5) which has ortho-quinone and spiro-methylcyclopropane moieties from Caryopteris mongolica. The compound showed antibacterial activity against Gram-positive bacteria: Staphylococcus aureus, $S$. epidermidis, Enterococcus faecalis, and Micrococcus lutens [42]. In addition, extracts and fractions from Comarum salesovianum (Rosaceae) showed inhibitory activity against the aforementioned strains. Consequently, the constituents of this plant were investigated by Odontuya and coworkers, and phenolic lipid derivatives possessing antibacterial properties were identified [43].

\section{Vectors of pathogens}

Various biting ticks and insects, such as lice, are known vectors of pathogens. These vectors are responsible for transmitting a number of protozoal, bacterial, and viral infectious diseases in humans and animals. Vector control is, therefore, 
one of the most important ways to prevent the transmission of these infectious diseases.

Dermacentor nuttalli is a tick known as one of the major unsanitary pests in Mongolia, and mediates infectious diseases between livestock. Banzragchgarav and coworkers examined 113 crude extracts of 76 plant species included in 26 families for anti-tick activity against $D$. nuttalli. The extracts from Amaranthus retroflexus (Amaranthaceae) roots, Ephedra sinica (Ephedraceae) leaves, Erigeron acer (Asteraceae) roots, Ranunculus japonicus (Ranunculaceae) roots, and Spiraea salicifolia (Rosaceae) leaves showed inhibitory activity against $D$. nuttalli [44].

The analyses of the active compounds and mechanisms of inhibition of the above-mentioned anti-tick plants are still ongoing. In addition, in an attempt to identify any plantvector (insect, tick, and lice) chemical interaction(s), we tried to estimate the effect(s) of phytochemicals in an insect model. Phenoloxidase is a component of the innate immune system of insects, which defends against foreign substances by producing melanin. In our study, an assay was developed for phenoloxidase activity using Acyrthosiphon pisum. The inhibitory effect against phenoloxidase of compounds from Atraphaxis frutescens (Polygonaceae) was estimated by Odonbayar and coworkers, by comparing the results with the 1,1-diphenyl-2-picrylhydrazyl (DPPH) radical scavenging activities and mushroom tyrosinase activities [45]. In the above study, gallocatechin (18, Fig. 4) and epigallocatechin (20, Fig. 4) were suggested to be key compounds that inhibit phenoloxidase. Furthermore, the activity of catechin (19, Fig. 4) was ten times higher than that of epicatechin (20, Fig. 4), which was confirmed by the experiments that were conducted using pure samples during an investigation of the chemical constituents from Calligonum mongolicum of the family Polygonaceae [46]. Brachanthemum gobicum is used to remove external parasites, such as the parasitic louse Linognathus, from domesticated sheep [33]. The characteristic acylated lignans have an isovaleryl moiety, which is released by the disassembly of the compounds. Therefore, the effect of the lignans against parasites is of interest.

\section{Effects on human and animal health}

Hyaluronic acid (HA) is one of the main elements of the body's extracellular matrix and has numerous functions in the skin, joints, and internal organs. Hyaluronidase is an enzyme that degrades HA. Inhibitors of hyaluronidase are expected to control the amount of HA, and inhibition activities of this enzyme have been hypothesized to relate to anti-allergic activity [56, 57]. Dracocephalum foetidum (Lamiaceae) is a herbal plant used to treat inflammatory conditions. Selenge and coworkers identified the hyaluronidase inhibitory phenylpropanoid oligomers, rosmarinic acid (32, Fig. 6), its derivative (33, Fig. 6), and flavonoids as chemical constituents of this plant [47]. Compounds showing hyaluronidase inhibitory activity were also found in plants belonging to the family Rosaceae, including Chamaerhodos erecta, C. altaica, and Dasiphora parvifolia. These compounds were identified as hydrolysable tannins, dimeric A-type proanthocyanidins, and catechins [48, 49]. Furthermore, various triterpene saponins have been reported as hyaluronidase inhibitors, with some of the active saponins that have oleanene-type triterpene aglycone (34-37, Fig. 6) being isolated from aerial parts of Oxytropis lanata by Buyankhishig and coworkers [34].

It is understood that antioxidants affect oxidative steps and generally decrease oxidative stresses in the body. DPPH radical scavenging activity is considered to be one of the indexes of antioxidant activity. Therefore, the radical scavenging activity of isolated compounds was determined [38, $45,47-50]$. Melanin, a skin pigment, is produced by the oxidation of amino acids, including tyrosine. Consequently, tyrosinase is an enzyme of concern during melanization, with some of the isolated anti-oxidative compounds showing tyrosinase inhibitory activity. Compounds containing 7-methoxyflavonols with pyrogallol B-ring moieties and myricitrin (38-42, Fig. 7), isolated from Atraphaxis frutescens, showed inhibitory activity against mushroom tyrosinase $\left(\mathrm{IC}_{50} 0.9-4.7 \mathrm{mM}\right)$ [45]. Advanced glycation end products (AGEs) are considered to induce and promote degenerative diseases, including diabetes and Alzheimer's. AGEs are produced from carbohydrates, amino acids, and proteins via various steps including oxidation. We evaluated the inhibitory activity of AGEs, and many constituents isolated from Chamaerhodos erecta and C. altaica showed activity [48]. Triterpenes having a $\gamma$-lactone ring were obtained from Abies sibirica, which belongs to the Pinaceae family. Five of these triterpenes showed low-density lipoprotein (LDL)-antioxidative activity, and some of the triterpenes showed lipase inhibitory activity [51]. Livestock palatability studies for plants containing anti-oxidative compounds have been reported. It was noted that camels prefer Atraphaxis frutescens during the summer, autumn, and winter seasons. This plant is thought to be an important component of mixed livestock feed because of its high nutrient values [20]. In addition, Chamaerhodos altaica is known to be a good forage plant for horses and small animals [20] while Dracocephalum foetidum is moderately consumed by camels in the summer season [20,21]. The next theme of our research work aims to focus on the chemical interactions of the identified plant compounds with livestock.

Cholinesterase is an enzyme regulating the levels of acetylcholine in various tissues of the body. Acetylcholinesterase (AChE) and butyrylcholinesterase (BChE) are largely involved in the neural transmission of synapses and their inhibitors have been identified as targets in the treatment of neurodegenerative disorders, including Alzheimer's diseases 
<smiles>O=C(/C=C/c1ccc(O)c(O)c1)O[C@H](Cc1ccc(O)c(O)c1)C(=O)O</smiles><smiles>COc1ccc(/C=C(\Oc2ccc(/C=C/C(=O)O[C@@H](Cc3ccc(O)c(O)c3)C(=O)O)cc2O)C(=O)O)cc1O</smiles>

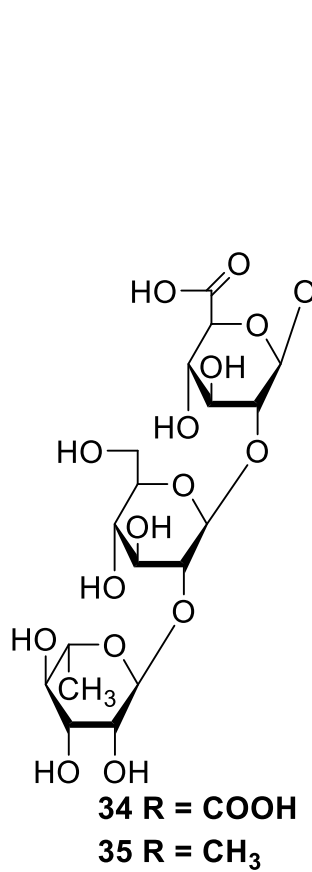<smiles>CCC(C)C1(C)CC[C@@H](O)C(C)(C)C1CO</smiles><smiles>[R]C1CC(=O)[C@]2(C)CC[C@]3(C)C(=CCC[C@@]3(C)CC)C2C1</smiles>

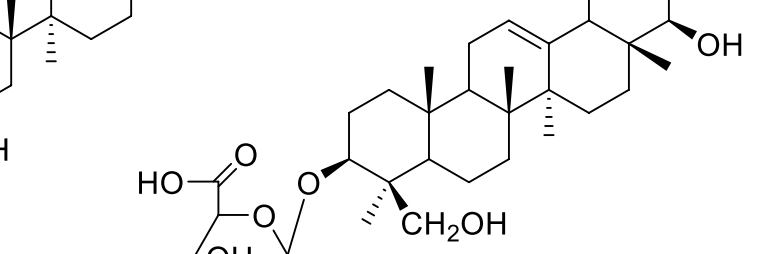

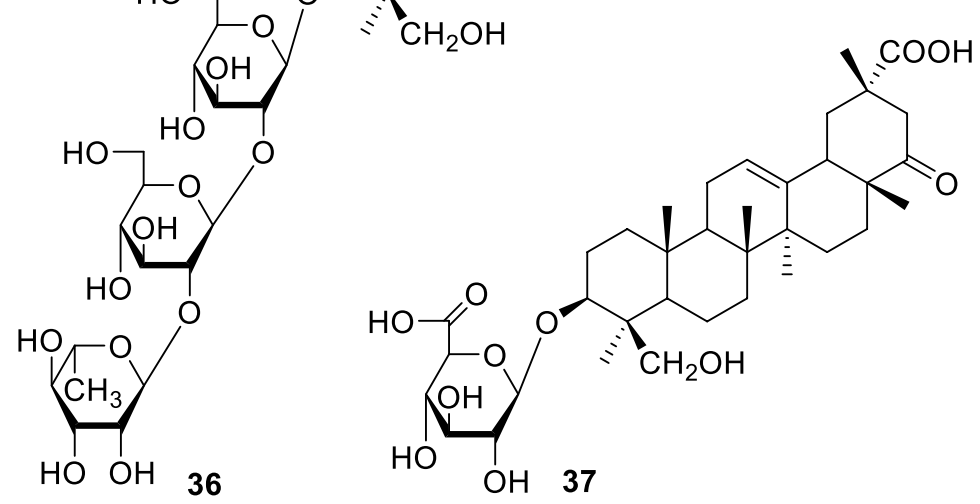

Fig. 6 Phenylpropanoid oligomers isolated from Dracocephalum foetidum (32 and 33) and saponins (34-37) from Oxytropis lanata possess hyaluronidase inhibitory activity

and myasthenia gravis [58]. Abietane-type diterpenoids (23-30, Fig. 5) from Caryopteris mongolica showed AChE and/or BChE inhibitory activity [52, 53]. Among these, compound $\mathbf{2 4}$ showed the highest activity (AChE from human erythrocytes: $\mathrm{IC}_{50} 19.2 \mu \mathrm{M}$; AChE from electric eel: $\mathrm{IC}_{50} 12.3 \mu \mathrm{M}$; BChE from horse serum: $\mathrm{IC}_{50} 7.70 \mu \mathrm{M}$ ). Although a new diterpenoid glucoside (31) was isolated, it did not show AChE or BChE inhibitory activity [52]. The diterpenoids have catechol moieties, and the absolute configuration of compound $\mathbf{3 0}$ was determined by X-ray crystallography [53]. Furthermore, some types of phenylpropanoid oligomers showed AChE and BChE inhibitory activity. Thymus gobicus (Lamiaceae) contained AChE and BChE inhibitory monardic acid A (43, Fig. 7) [54], which had the $7 R, 8 R$-configuration instead of the $7 S, 8 S$-configuration of lithospermic acids as a structural feature [59].

\section{Chemical interactions between forage plants and livestock}

Pulsatilla genus plants are termed "Yargui" in Mongolia. The flowers of Yargui are traditionally welcomed by nomads because they are regarded as a tonic for livestock that has survived the harsh winter, specifically, goats and sheep [20, 21]. Moreover, consuming the meat and milk of livestock that has fed on early spring Yargui flowers is seen as a promise of a healthy life for the year by the nomadic people [40]. Pulsatilla flavescens (Ranunculaceae) is a perennial herb commonly called yellow Yargui by the nomadic people. Ganchimeg and coworkers investigated the constituents of the flower, and obtained numerous flavonoids [40]. Although the reasons behind the tonic effects have not been established, we will approach the important traditions of nomadic people and their livestock from a scientific perspective as a next step.

Artemisia sieversiana is an annual herbaceous plant named "tsarvant sharilj." Its flower is used to treat fever, throat inflammation, and pneumonia in Mongolia. Although the plant is thought to be a forage plant, livestock preferences for the plant differ by season [20,21]. For example, it is most palatable to camels, goats, and sheep in spring but is not consumed by the livestock during summer. Although the livestock consume withered A. sieversiana after autumn, nomadic people have noted the production of meat and milk 
<smiles>[R]Oc1cc(O)c2c(=O)c(O[C@@H]3O[C@H](C)[C@@H](O)[C@H](O)[C@H]3O)c(-c3cc(O)c(O)c(O)c3)oc2c1[R2]</smiles>

$38 \mathrm{R}_{1}=\mathrm{Me}, \mathrm{R}_{2}=0$ - $\beta$-D-glucopyranosyl,

$39 \mathrm{R}_{1}=\mathrm{Me}, \mathrm{R}_{2}=$ O-acetyl,

$40 \mathrm{R}_{1}=\mathrm{Me}, \mathrm{R}_{2}=\mathrm{OH}$,

$41 \mathrm{R}_{1}=\mathrm{Me}, \mathrm{R}_{2}=\mathrm{H}$

$42 \mathrm{R}_{1}=\mathrm{H}, \mathrm{R}_{2}=\mathrm{H}$,<smiles>O=C(/C=C/c1ccc(O)c2c1[C@H](C(=O)O)[C@H](c1ccc(O)c(O)c1)O2)O[C@@H](Cc1ccc(O)c(O)c1)C(=O)O</smiles>

Fig. 7 Flavonoid glycosides isolated from Atraphaxis frutescens (3842) possess tyrosinase inhibitory activity and monardic acid A (43) isolated from Thymus gobicus possesses cholinesterase inhibitory activity

with an unpleasant odor and flavor during this period. In an attempt to identify the chemical constituents of this plant, Nurbek and coworkers isolated sesquiterpenoids (44-46, Fig. 8), dimers of sesquiterpenoids, flavonoids, lignans, and quinic acid derivatives [35]. The absolute configuration of compound 44 was established using single-crystal X-ray diffraction, and the isolated sesquiterpenoids from Mongolian A. sieversiana were different from known isomers [35]. Although the main constituents of this plant have been identified, the reason(s) as to why the plant has undesirable effects on the meat and milk of livestock after autumn still needs to be established.

\section{Future development}

Research on the structure-activity relationship of natural and synthesized compounds to identify compounds targeting Trypanosoma species and various pathogens has already

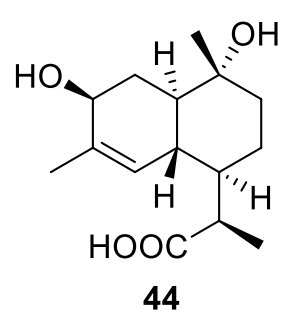

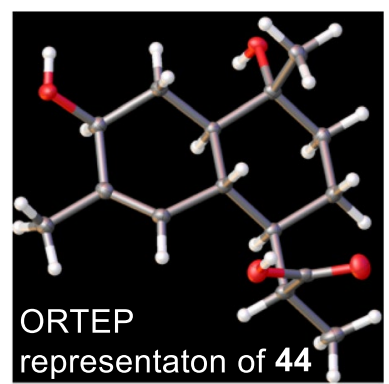

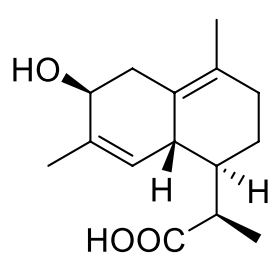

45

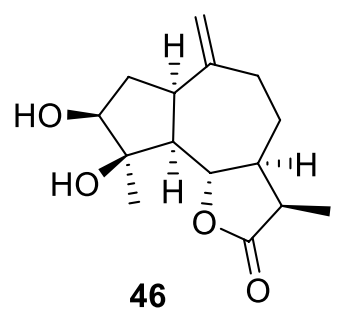

46
Fig. 8 Sesquiterpenoids isolated from Artemisia sieversiana (44-46)

started. To control infectious diseases, it is important to study not only pathogens but also their vectors; hence, we are investigating the chemical interactions involved in their biological mechanisms. Cholinesterase is a target for pesticides, and selective acetylcholine inhibitors have been used to produce insecticides. In our experiments, although the effects of plant compounds on human and animal cholinesterase were evaluated [52-54], their selectivity against animal and pest species including the detailed mechanisms of their effects on enzymes have to be considered. Furthermore, the effects of plant-derived compounds on the innate immune system of insects and ticks are interesting themes for future research [45, 46].

It is generally thought that many plant metabolites are produced by evolutionary (and sometimes coevolutionary) mechanisms based on the results of interactions between plants and insects, animals, microorganisms, and environmental conditions. Plants have been shown to influence the health of animals through their chemical constituents. For example, some of the genus Oxytropis plants such as $O x y$ tropis glabra are known as toxic plants because they contain an indolizidine alkaloid, swainsonine, which causes lethal neurological disorders [60]. However, although there is no knowledge on the toxic constituent(s) of Oxytropis lanata, the biologically active oxazoles and saponins can be beneficial [32, 34]. Furthermore, even though $O$. lanata is not palatable in pasture lands [21], it would be of interest to know whether these plants are good forage or medicinal plants. Research on their phytochemicals would be able to provide further information.

Brachanthemum gobicum have isovaleryl moieties in lignans [33], and isovaleric acid is easily released by their hydrolysis. Although B. gobicum are known as desirable 
forage plants for camels in spring and autumn [20,21], humans perceive isovaleric acid as having a strong unpleasant odor. An area of interest would be the effect of isovaleric acid on animals, including plant palatability and repellent properties. For goats and sheep, smell and taste are important senses that are used to judge edible plants. In addition, it has been shown that herbivorous insects are stimulated to feed by nutritional and plant secondary components [61]. However, the compounds and tastes that stimulate the foraging behaviors of herbivorous livestock are yet to be determined [62]. Livestock in Mongolia rotate their feeding fields depending on the seasons and environmental conditions. They tend to judge and know nutritious or toxic plants of the flora that keeps changing every season.

Available scientific data are currently not enough to understand the interactions in complex ecosystems. However, continuous research based on chemical, biological, and ecological approaches to study the interactions between livestock and wild plants will present new ideas on how to treat severe infectious diseases in both humans and livestock.

\section{Conclusions}

The characteristic chemical constituents from Mongolian medicinally useful plants were isolated and their biological activities were studied. For example, 2,5-diphenyloxazoles isolated from Oxytropis lanata and acylated-lignans isolated from Brachanthemum gobicum are Trypanocidal compounds. Galloyl moieties are expected to be one of the key structures showing anti-piroplasm activities as postulated from the results of the research on plants belonging to the family Saxifragaceae. The phytochemicals that can potentially prevent vector problems were investigated. Some plant extracts and phenoloxidase inhibitory compounds were found to be potential inhibitors of Dermacentor nuttalli and unsanitary insects. Flavonoids, phenylpropanoid derivatives, and phenolic compounds from Atraphaxis frutescens and some Dracocephalum plants showed hyaluronidase inhibitory and/or radical scavenging activity. Catechins and their analogs were isolated from many plants during our study and they may have key roles in exerting pharmacological and biological effects. They may be useful against stressful lifestyles and can thus, contribute to the care and well-being of humans and animals.

There are many potent plant sources in the nomadic habitats of Mongolia and significant traditional knowledge possessed by this population. These attributes need to be studied in depth to determine their suitability for sustainable application. The chemical constituents of these plants are an informative foundation for the scientific understanding of the ecology related to nomadism, which may provide numerous ideas for better and healthier human lives.
Supplementary Information The online version contains supplementary material available at https://doi.org/10.1007/s11418-021-01529-7.

Acknowledgements We thank Dr. K. Suganuma and Dr. B. Tuvshintulga from the National Research Center for Protozoan Diseases, Obihiro University of Agriculture and Veterinary Medicine, for providing photos of Trypanosoma, Babesia, and Theileria. The authors acknowledge that coworkers contributed equally to this work. We referenced papers authored by laboratory members of the University of Mongolia, Mongolian University of Pharmaceutical Sciences, Mongolian Academy of Sciences, Institute of Veterinary Medicines, Mongolian University of Life Sciences, Obihiro University of Agriculture and Veterinary Medicine, University of Shizuoka, and Tohoku Medical and Pharmaceutical University, and we acknowledge their efforts in these research projects. We are grateful to Dr. F. Yoshizaki, Dr. K. Sasaki, Dr. Y. Ishikawa, Dr. N. Inoue, Dr. I Igarashi, Dr. H. Noguchi, and Dr. T. Miyase for providing us with valuable advice. We would like to thank Editage (www.editage.com) for English language editing.

Funding This work was financially supported by JSPS Kakenhi (JP21H02638, JP19K16397, JP26860068), JICA M-JEED project, JST/JICA SATREPS (JPMJSA1906), the Kanno Foundation of Japan, a Cooperative Research Grant from the National Research Center for Protozoan Diseases, Obihiro University of Agriculture and Veterinary Medicine, and Kanae foundation.

\section{Declarations}

Conflict of interest The authors declare no conflict of interest.

Open Access This article is licensed under a Creative Commons Attribution 4.0 International License, which permits use, sharing, adaptation, distribution and reproduction in any medium or format, as long as you give appropriate credit to the original author(s) and the source, provide a link to the Creative Commons licence, and indicate if changes were made. The images or other third party material in this article are included in the article's Creative Commons licence, unless indicated otherwise in a credit line to the material. If material is not included in the article's Creative Commons licence and your intended use is not permitted by statutory regulation or exceeds the permitted use, you will need to obtain permission directly from the copyright holder. To view a copy of this licence, visit http://creativecommons.org/licenses/by/4.0/.

\section{References}

1. Urgamal M, Gundegmaa V, Baasanmunkh Sh, Oyuntsetseg B, Darikhand D, Munkh-Erdene T (2019) Additions to the vascular flora of Mongolia-IV. Proc Mongolian Acad Sci 59:41-53

2. Ministry of food, agriculture and light industry of Mongolia. Sixth national report to the convention on biological diversity. https:// www.cbd.int/doc/nr/nr-06/mn-nr-06-en.pdf. Accessed 12th January 2021.

3. Takano F, Yoshizaki F, Fushiya S, Hayasaka H, Ohba K, Batkhuu J, Sanchir C, Boldsaikhan B (2003) Mongolian traditional medicine and medicinal plants. Kampo Med 54:963-972

4. Pitschmann A, Purevsuren S, Obmann A, Natsagdorj D, Gunbilig D, Narantuya S, Kletter Ch, Glasl S (2013) Traditional Mongolian Medicine: history and status quo. Phytochem Rev 12:943-959

5. Zolboo B, Toume K, Batkhuu J, Kazuma K, Cai SQ, Hayashi S, Atsumi T, Yoshitomi T, Uchiyama N, Maruyama T, Kawahara N, Komatsu K (2021) Characterization of metabolites 
in Saposhnikovia divaricata root from Mongolia. J Nat Med 75:11-27

6. Odontuya G, Daowan L, Purevdorj PP (2017) Pancreatic lipase inhibitory and antioxidative constituents from the aerial parts of Paeonia lactiflora Pall. Phytochemistry Lett 21:240-246

7. Makkar HPS, Norvsambuu T, Lkhagvatseren S, Becker K (2009) Plant secondary metabolites in some medicinal plants of Mongolia used for enhancing animal health and production. Tropicultura 27:159-167

8. Urgamal M, Erdenetuya B, Munkh-Erdene T, Otgonchuluun S, Zoltsetseg C, Khureltsetseg L, Kwon O (2018) Medicinal plant diversity in the southern and eastern Gobi Desert region. Mongolia J Ecol Environ 42:4

9. Yunatov AA. (1950) Main Patterns of the Vegetation Cover of the Mongolian People's Republic. Proceedings of the Mongolian Commission, 39, Publishing House of the USSR Academy of Sciences, Moscow

10. Bayartogtokh B, Aibek U, Yamane S, Pfeiffer M (2014) Diversity and biogeography of ants in Mongolia (Hymenoptera: Formicidae). Asian Myrmecol 6:63-82

11. Sanchir Ch, Komatsu K, Batkhuu J, Boldsaikhan B, Fushimi H (2003) JICA, Colored illustrations of Mongolian useful plants. Admon print, Ulaanbaatar

12. Batkhuu J, Sanchir C, Ligaa U, Jamsran T (2005) Colored illustrations of Mongolian useful plants, vol 2. Admon print, Ulaanbaatar

13. Ligaa U, Davaasuren B, Ninjil N (2005) Medicinal plants of Mongolia used in Western and Eastern medicine. JKC printing, Ulaanbaatar

14. WHO 2013 Medicinal plants in Mongolia: WHO press, Geneva. https://apps.who.int/iris/handle/10665/207671. Accessed January 7, 2021

15. Batsuren D (2018) 45th anniversary of Laboratory of Natural Product Chemistry of the Institute of Chemistry and Chemical Technology. Bulletin of the Institute of Chemistry and Chemical Technology 2018(6), Mongolian Academy of Sciences, Soyombo press, Ulaanbaatar, Mongolia. https://www.mongoliajol.info/ index.php/BICCT/issue/view/113. Accessed January 13, 2021

16. Ministry of food, agriculture and light industry of Mongolia (2014) Convention on biological diversity, The 5th national report of Mongolia. Mongolica Publishing, Ulaanbaatar

17. JICA 2017 Data collection survey for agriculture and livestock Final report: Japan International Cooperation Agency; ALMEC Corporation; IC NET Co., Ltd.; EXEIDEA Ltd., https://openjicare port.jica.go.jp/340/340/340_115_12285466.html. Accessed February 12,2020

18. Ministry of food, agriculture, and light industry of Mongolia. http://mofa.gov.mn/exp/blog/10/253. Accessed February 12, 2020

19. Mongolian Statistical Information Service. https://www.1212.mn/. Accessed January 12, 2021

20. Jigjidsuren S, Johnson DA (2003) Forage plants in Mongolia. Admon press, Ulaanbaatar

21. Damiran D (2005) Palatability of Mongolian Rangeland Plants. Eastern Oregon Agricultural Research Center/Union Station. https://www.researchgate.net/publication/234046199. Accessed February 12, 2020

22. Suganuma K, Narantsatsral S, Battur B, Yamasaki S, Otgonsuren D, Musinguzi SP, Davaasuren B, Battsetseg B, Inoue N (2016) Isolation, cultivation and molecular characterization of a new Trypanosoma equiperdum strain in Mongolia. Parasit Vectors 9:481

23. Battsetseg B, Sivakumar T, Naranbaatar K, Narantsatsral S, Myagmarsuren P, Enkhtaivan B, Davaasuren B, Mizushima D, Weerasooriya G, Igarashi I, Battur B, Yokoyama N (2018) Serosurvey of Babesia bovis and Babesia bigemina in cattle in Mongolia. Vet Parasitol Reg Stud Reports 13:85-91
24. Boldbaatar D, Xuan X, Battsetseg B, Igarashi I, Battur B, Batsukh Z, Bayambaa B, Fujisaki K (2005) Epidemiological study of equine piroplasmosis in Mongolia. Vet Parasitol 127:29-32

25. Rao MP, Davi NK, D'Arrigo RD, Skees NB, Leland C, Lyon B, Wang SY, Byambasuren O (2015) Dzuds, droughts, and livestock mortality in Mongolia. Environ Res Lett 10:074012

26. Battsetseg B, Xuan X, Ikadai H, Bautista JLR, Byambaa B, Boldbaatar D, Battur B, Battsetseg G, Batsukh Z, Igarashi I, Nagasawa H, Mikami T, Fujisaki K (2001) Detection of Babesia caballi and Babesia equi in Dermacentor nuttalli adult ticks. Int J Parasitol 31:384-386

27. Riehm JM, Vergnaud G, Kiefer D, Damdindorj T, Dashdavaa O, Khurelsukh T, Zöller L, Wölfel R, Flèche PL, Scholz HC (2012) Yersinia pestis lineages in Mongolia. PLoS ONE 7:e30624

28. Devi S (2020) Infectious diseases upsurge in Mongolia. Lancet Infect Dis 20:289

29. NSOM (National Statistics Office of Mongolia). Mongolian Statistical Yearbook. National Statistics Office of Mongolia, Ulaanbaatar. https://www.en.nso.mn/. Accessed January 7, 2021

30. Wei Y, Zhen L (2020) The dynamics of livestock and its influencing factors on the Mongolian Plateau. Environ Dev 34:100518

31. Kinugasa T, Ishibashi K, Miyawaki M, Gantsetseg B (2019) Germination characteristics and phytotoxic inhibition of germination in Artemisia adamsii, a low-palatability weed in the Mongolian steppe. Seed Sci Res 29:197-203

32. Banzragchgarav O, Murata T, Odontuya G, Buyankhishig B, Suganuma K, Davaapurev B, Inoue N, Batkhuu J, Sasaki K (2016) Trypanocidal activity of 2,5-diphenyloxazoles isolated from the roots of Oxytropis lanata. J Nat Prod 79:2933-2940

33. Odonbayar B, Murata T, Suganuma K, Ishikawa Y, Buyankhishig B, Batkhuu J, Sasaki K (2019) Acylated lignans from Brachanthemum gobicum and their trypanocidal activity. J Nat Prod 82:774-784

34. Buyankhishig B, Murata T, Suganuma K, Batkhuu J, Sasaki K (2020) Hyaluronidase inhibitory saponins and a trypanocidal isoflavonoid from the aerial parts of Oxytropis lanata. Fitoterapia 145:104608

35. Nurbek S, Murata T, Suganuma K, Ishikawa Y, Buyankhishig B, Kikuchi T, Byambajav T, Davaapurev B, Sasaki K, Batkhuu J (2020) Isolation and evaluation of trypanocidal activity of sesquiterpenoids, flavonoids, and lignans in Artemisia sieversiana collected in Mongolia. J Nat Med 74:750-757

36. Naranmandakh S, Murata T, Odonbayar B, Suganuma K, Batkhuu J, Sasaki K (2018) Lanostane triterpenoids from Fomitopsis officinalis and their trypanocidal activity. J Nat Med 72:523-529

37. Suganuma K, Murata T, Molefe NI, Sandagdorj N, Banzragchgarav O, Odonbyar B, Batdorj D, Mizushima D, Batkhuu J, Sasaki K, Buttur B, Battsetseg B, Inoue N (2017) Establishment of in vitro drug sensitivity assay against $T$. equiperdum Mongolian strains and the screening of trypanocidal compounds extracted from Mongolian herbal plants. Mongolian J Vaterinary Med 3:24-26

38. Badral D, Odonbayar B, Murata T, Munkhjargal T, Tuvshintulga B, Igarashi I, Suganuma K, Inoue N, Brantner AH, Odontuya G, Sasaki K, Batkhuu J (2017) Flavonoid and galloyl glycosides isolated from Saxifraga spinulosa and their antioxidative and inhibitory activities against species that cause piroplasmosis. J Nat Prod 80:2416-2423

39. Banzragchgarav O, Murata T, Tuvshintulga B, Suganuma K, Igarashi I, Inoue N, Batkhuu J, Sasaki K (2019) Chemical constituents of Bergenia crassifolia roots and their growth inhibitory activity against Babesia bovis and B. bigemina. Phytochem Lett 29:79-83

40. Ganchimeg D, Batbold B, Murata T, Davaapurev BO, Munkhjargal T, Tuvshintulga B, Suganuma K, Igarashi I, Buyankhishig B, Sasaki K, Batsuren D, Batkhuu J (2019) Flavonoids isolated 
from the flowers of Pulsatilla flavescens and their anti-piroplasm activity. J Nat Med 73:633-640

41. Takeda Y, Murata T, Jamsransuren D, Suganuma K, Kazami Y, Batkhuu J, Badral D, Ogawa H (2020) Saxifraga spinulosaderived components rapidly inactivate multiple viruses including SARS-CoV-2. Viruses 12:699

42. Saruul E, Murata T, Selenge E, Sasaki K, Yoshizaki F, Batkhuu J (2015) An antibacterial ortho-quinone diterpenoid and its derivatives from Caryopteris mongolica. Bioorg Med Chem Lett 25:2555-2558

43. Odontuya G, Banzragchgarav O, Murata T, Batkhuu J, Sasaki K, Yoshizaki F (2015) Antibacterially active phenolic lipid derivatives from Comarum salesovianum (Steph.) Aschers. et Gr. Phytochem Lett 13:360-364

44. Banzragchgarav O, Battur B, Battsetseg B, Myagmarsuren P, Murata T, Batkhuu J (2019) Acaricidal activity of Mongolian plants against Dermacentor nuttalli. Mong J Agric Sci 28:26-33

45. Odonbayar B, Murata T, Batkhuu J, Yasunaga K, Goto R, Sasaki K (2016) Antioxidant flavonols and phenolic compounds from Atraphaxis frutescens and their inhibitory activities against insect phenoloxidase and mushroom tyrosinase. J Nat Prod 79:3065-3071

46. Buyankhishig B, Murata T, Odonbayar B, Batkhuu J, Sasaki K (2021) New compounds from the aerial parts of Calligonum mongolicum. Phytochemistry Lett 41:147-151

47. Selenge E, Murata T, Tanaka S, Sasaki K, Batkhuu J, Yoshizaki F (2014) Monoterpene glycosides, phenylpropanoids, and acacetin glycosides from Dracocephalum foetidum. Phytochemistry 101:91-101

48. Selenge E, Odontuya G, Murata T, Sasaki K, Kobayashi K, Batkhuu J, Yoshizaki F (2013) Phytochemical constituents of Mongolian traditional medicinal plants, Chamaerhodos erecta and C. altaica, and its constituents prevents the extracellular matrix degradation factors. J Nat Med 67:867-875

49. Murata T, Selenge E, Suganuma K, Asai Y, Batkhuu J, Yoshizaki F (2013) Chromone acyl glucosides and an ayanin glucoside from Dasiphora parvifolia. Phytochemistry Lett 6:552-555

50. Selenge E, Murata T, Kobayashi K, Batkhuu J, Yoshizaki F (2013) Flavone tetraglycosides and benzyl alcohol glycosides from the Mongolian medicinal plant Dracocephalum ruyschiana. J Nat Prod 76:186-193

51. Handa M, Murata T, Kobayashi K, Selenge E, Miyase T, Batkhuu J, Yoshizaki F (2013) Lipase inhibitory and LDL anti-oxidative triterpenes from Abies sibirica. Phytochemistry 86:168-175

52. Murata T, Selenge E, Oikawa S, Ageishi K, Batkhuu J, Sasaki K, Yoshizaki F (2015) Cholinesterase-inhibitory diterpenoids and chemical constituents from aerial parts of Caryopteris mongolica. J Nat Med 69:471-478

\section{Authors and Affiliations}

\section{Toshihiro Murata $^{1}$ (D) . Javzan Batkhuu ${ }^{2}$}

Toshihiro Murata murata-t@tohoku-mpu.ac.jp

1 Division of Pharmacognosy, Tohoku Medical and Pharmaceutical University, 4-1 Komatsushima 4-chome, Aoba-ku, Sendai 981-8558, Japan
53. Murata T, Ishikawa Y, Saruul E, Selenge E, Sasaki K, Umehara K, Yoshizaki F, Batkhuu J (2016) Abietane-type diterpenoids from the roots of Caryopteris mongolica and their cholinesterase inhibitory activities. Phytochemistry 130:152-158

54. Odonbayar B, Murata T, Matsumoto N, Batkhuu J, Sasaki K (2016) Chemical constituents of aerial parts of Thymus gobicus and their cholinesterase inhibitory activities. Mongolian J Chem $17: 14-17$

55. Odontuya G, Murata T, Sasaki K, Yoshizaki F (2015) Non-polar constituents from Tarazacum officinale Weber ex Wigg. Mongolian Pharm Pharmacol 2:65-71

56. Girish KS, Kemparaju K, Nagaraju S, Vishwanath BS (2009) Hyaluronidase inhibitors: a biological and therapeutic perspective. Curr Med Chem 16:2261-2288

57. Murata T, Tatsuo Katagiri T, Osaka M, Yamauchi S, Yoshimura K, Kawada M, Fujii Y, Suzukia Y, Sasaki K (2021) Hyaluronidase and degranulation inhibitors from the edible roots of Oenanthe javanica including seric acids $\mathrm{F}$ and $\mathrm{G}$ that were obtained by heating. Biosci Biotechnol Biochem. https://doi.org/10.1093/bbb/ zbaa042

58. Campiani G, Fattorusso C, Butini S, Gaeta A, Agnusdei M, Gemma S, Persico M, Catalanotti B, Savini L, Nacci V, Novellino E, Holloway HW, Greig NH, Belinskaya T, Fedorko JM, Sazena A (2005) Development of molecular probes for the identification of extra interaction sites in the mid-gorge and peripheral sites of butyrylcholinesterase (BuChE). Rational design of novel, selective, and highly potent BuChE inhibitors. J Med Chem 48:1919-1929

59. Murata T, Oyama K, Fujiyama M, Oobayashi B, Umehara K, Miyase T, Yoshizaki F (2013) Diastereomers of lithospermic acid and lithospermic acid B from Monarda fistulosa and Lithospermum erythrorhizon. Fitoterapia 91:51-59

60. Takeda S, Tanaka H, Shimada A, Morita T, Ishihara A, Adilbish A, Delgermaa B, Gungaa O (2014) Cerebellar ataxia suspected to be caused by Oxytropis glabra poisoning in western Mongolian goats. J Vet Med Sci 76:839-846

61. Murata T, Mori N, Nishida R (2011) Larval feeding stimulants for a Rutaceae-feeding swallowtail butterfly, Papilio xuthus L. in Citrus unshiu Leaves. J Chem Ecol 37:1099-1109

62. Forbey JS, Dearing MD, Gross EM, Orians CM, Sotka EE, Foley WJ (2013) A pharm-ecological perspective of terrestrial and aquatic plant-herbivore interactions. J Chem Ecol 39:465-480

Publisher's Note Springer Nature remains neutral with regard to jurisdictional claims in published maps and institutional affiliations.

2 School of Engineering and Applied Sciences, National University of Mongolia, POB-617/46A, Ulaanbaatar 14201, Mongolia 